\title{
CHARACTERIZATION OF MARKER CHROMOSOMES BY FISH USING MICRODISSECTED PROBES FROM OLD CARNOY-FIXED CELLS: REPORT OF TWO CASES
}

\author{
Yasutsugu Chinen, ${ }^{*}$ Takaya ToHma, Yoshinori IzUmikawa, \\ Kenji Naritomi, and Kiyotake Hirayama \\ Department of Pediatrics, University of the Ryukyus School of Medicine, \\ 207 Uehara, Nishihara, Okinawa 903-01, Japan
}

\begin{abstract}
Summary We reported on two patients with a de novo marker chromosome of which the origins were successfully identified by FISH using microdissected probes. These probes were established by microdissections of extra chromosomal segments from Carnoy-fixed cells stored at $-20^{\circ} \mathrm{C}$ for several years. Using these probes, we could verify partial $1 \mathrm{q} 32$ trisomy in a patient with $17 \mathrm{p}+$ as well as partial $16 \mathrm{q} 2$ trisomy in another patient with $4 \mathrm{p}+$.

Key Words microdissection, fluorescent in situ hybridization (FISH), marker chromosome, de novo chromosome rearrangement
\end{abstract}

\section{Introduction}

It is difficult to know the origin of a de novo marker chromosome by conventional G- or R-banding techniques, especially when its extra segment is too short to compare the banding pattern or banding pattern is nonspecific. This is a reason why most patients with these chromosomal abnormalities are provided an inadequate genetic counseling, even though they have multiple congenital anomalies and mental retardation.

Recently, a microdissection technique of chromosome and subsequent amplification of the dissected chromosomal segments by polymerase chain reaction (PCR) have been developed. Three different techniques have been designed to amplify DNA templates from the dissected chromosome; (1) linker adapter-PCR (LA-PCR) (Lüdecke et al., 1989; Deng et al., 1992; Hirota et al., 1992), (2) degenerate oligonucleotide-primed PCR (DOP-PCR) (Guan et al., 1992; Meltzer et al., 1992; Telenius et al., 1992), and (3) DOP-Shuttle-PCR (Yokoyama and

\footnotetext{
Received June 16, 1997; Revised version accepted July 23, 1997
}

* To whom correspondence should be addressed. 
Sakuragawa, 1995). By using the PCR products as a probe pool, fluorescence in situ hybridization (FISH) combined with chromosome in situ suppression (CISS) hybridization may characterize the nature of chromosomal rearrangements. These methods have been applied for precise definition of an interstitial deletion (Rubtsov et al., 1996), a breakpoint region in human B-cell lymphoma (Guan et al., 1996), prenatal diagnosis of a marker chromosome (Müller-Navia et al., 1995), and characterization of a marker chromosome or translocations (Deng et al., 1992; Ohta et al., 1993; Ohashi et al., 1994; Müller-Navia et al., 1995; Eggermann et al., 1996; Engelen et al., 1996). Here we reported on two patients with a marker chromosome identified its origins by FISH using a microdissected probe pool established from Carnoy-fixed cells stored at $-20^{\circ} \mathrm{C}$ for several years.

\section{Materials and Methods}

Clinical reports and cytogenetics. Patient A was 2-year-old girl with severe psychomotor retardation, failure to thrive, and multiple congenital defects. She had dysmorphic facies with large fontanelle, frontal bossing, deep-set eyes, posteriorly rotated and low-set ears, bilateral cleft lips, cleft palate and micrognathia. Other findings included limited extension at the elbows, delayed bone age, Dandy-Walker malformation, and left hydronephrosis.

Patient $\mathrm{B}$ was referred to us at 3 years of age for psychomotor and growth retardation and a marker chromosome $4 \mathrm{p}+$. She had mildly triangular facies with frontal bossing, telecanthus, downslanting palpebral fissures, iris coloboma, high and wide nasal bridge, wide philtrum, and short neck. Her extremities showed limited pronation and spination at the wrists, limited extension at the elbows, brachyclinodactyly of fifth fingers, and large halluces.

Chromosomal analyses of the patients and their parents were performed on phytohemagglutinin-stimulated lymphocytes using standard G-banding techniques.

Microdissection and amplification of dissected DNA. The procedure for chromosome microdissection was performed essentially as described previously (Deng et al., 1992; Hirota et al., 1992; Ohta et al., 1993). Briefly, for preparation of metaphase chromosomes, Carnoy-fixed (methanol : acetic acid $=3: 1$ ) cell suspensions stored at $-20^{\circ} \mathrm{C}$ for $11 / 2$ years (patient $\mathrm{A}$ ) and $41 / 2$ years (patient B) were spread onto each clean glass-slide. Immediately the slides were washed in phosphate buffer ( $\mathrm{pH} \mathrm{6.8)}$ ) for $10 \mathrm{~min}$, and were rinsed in two changes of $70 \%$ ethanol. GTG-banding was performed with $0.0005 \%$ trypsin and $3 \%$ Giemsa at room temperature. Thirty pieces of the target chromosome were microdissected with a fine glass needle under an inverted microscope. They were transferred into a collection chamber and were covered with paraffin oil. Further steps, including proteinase $\mathrm{K}$ digestion, DNA extraction, Sau3Al digestion, DNA ligation to a linker/primer set, and PCR, were carried out as described previously (Hirota et al., 1992). Takara Ex Taq (Code No. RR00lA) was used as a DNA polymerase. 
The size of the PCR products ranged from 200 to $700 \mathrm{bp}$.

Fluorescence in situ hybridization (FISH). The PCR products from the dissected target chromosome were labeled with biotin-11-dUTP by a secondary PCR as described previously (Ohta et al., 1993). After an addition of $10 \mu \mathrm{g}$ Salmon sperm DNA (D-1626, Sigma), and $5 \mu \mathrm{g}$ human Cot-1 DNA (5279SA, Gibco BRL) as a competitor into a $1 / 20$ volume of the second PCR product, the DNA mixture was ethanol-precipitated, resuspended in $10 \mu \mathrm{l}$ formamide, denatured at $75^{\circ} \mathrm{C}$ for $10 \mathrm{~min}$, and mixed with a hybridization solution consisting of 20 $\mathrm{mg} / \mathrm{ml}$ bovine serum albumin, $10 \times \mathrm{SSC}$ and $50 \%$ dextran sulfate in a volume ratio of $1: 2: 2$. The hybridization mixture was incubated at $37^{\circ} \mathrm{C}$ for $30 \mathrm{~min}$, and was put onto denatured chromosomes. Overnight hybridization was performed at $37^{\circ} \mathrm{C}$. Further steps, including washing, incubation with fluorescence isothiocyanate (FITC)-conjugated avidin, counterstaining with propidium iodide (PI), were carried out as described previously (Ohta et al., 1993). Photomicroscopy was performed under a fluorescence microscope equipped with a B-2A filter (Nikon).

Results

Patient A. On the analysis of GTG-banded chromosomes, one chromosome 17 had an extra segment on the short arm. Karyotypes of the parents were normal. Her karyotype was designated as $46, \mathrm{XX}, 17 \mathrm{p}+$ (Fig. la). With a probe pool established from 30 dissected fragments of $17 \mathrm{p}+$, FISH on control metaphases painted distal fourth regions of chromosomes $1 \mathrm{q}$ as well as terminal segments of normal 17 p (Fig. 2a). To ensure these results, with a probe pool established from microdissected fragments of the distal half region of normal chromosome 1q, FISH on the patient metaphases painted distal half regions of chromosomes $\mathrm{lq}$ and $17 p+$, but not normal 17p (Fig. 2b). As a result of G-banding pattern and FISH analyses, we concluded that she has partial trisomy for 1q32-qter.

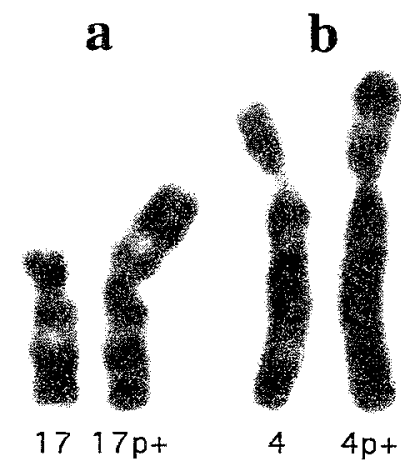

Fig. 1. a: A GTG-banded marker chromosome of patient A. b: A GTG-banded marker chromosome of patient $B$.

Vol. 42, No. 4, 1997 
Patient B. Cytogenetic analysis of GTG-banded chromosomes confirmed an extra band on $4 \mathrm{p}(4 \mathrm{p}+$ ) (Fig. 1b). With a probe pool from 25 dissected fragments of chromosome $4 p+$, FISH on control metaphases showed signals in distal regions of chromosomes $16 q$ and almost all segments of chromosomes $4 p$ (Fig. 2c). With a reverse probe pool made from microdissected fragments of normal $16 \mathrm{q}$ including a candidate region, FISH on the patient metaphases showed painting of normal $16 \mathrm{q}$ and an interstitial region of $4 \mathrm{p}+$ (Fig. 2d). As a result of $\mathrm{G}$-banding pattern and FISH analyses, we concluded that she might have partial trisomy for a part of 16q22-qter, which probably is inserted into the short arm of chromosome 4.
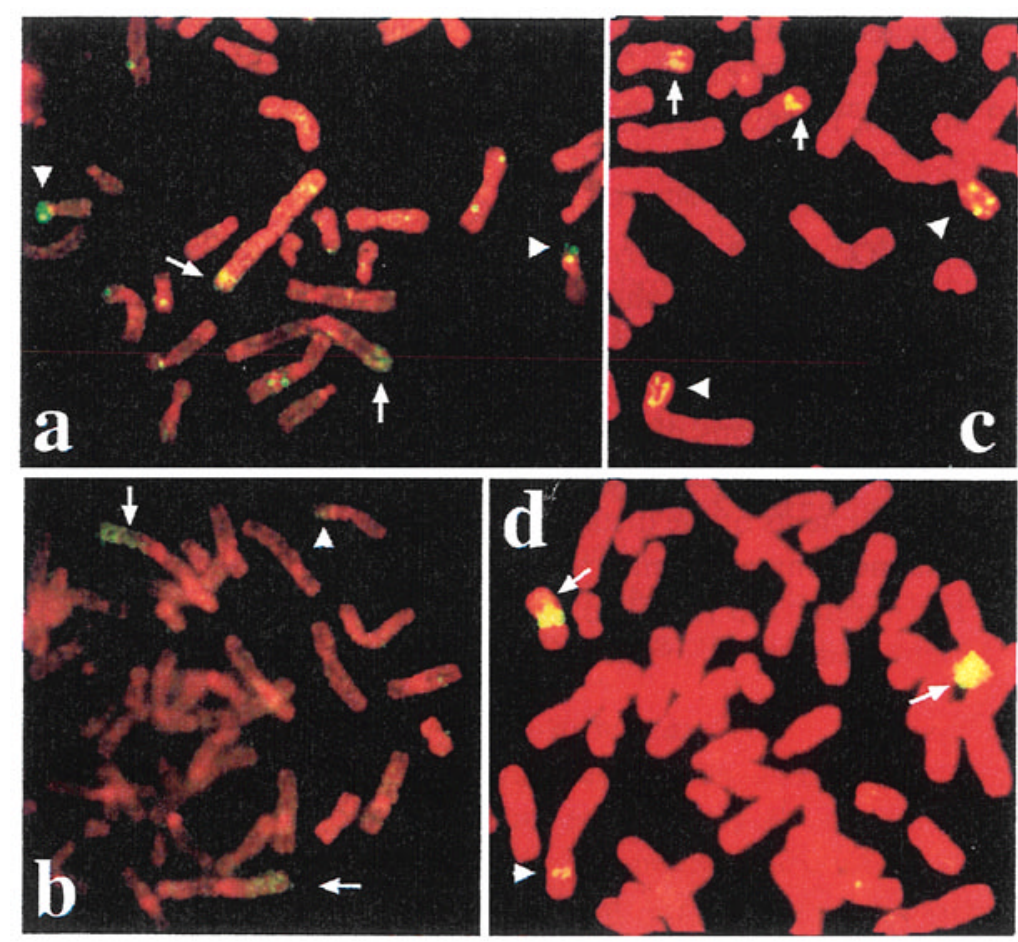

Fig. 2. a: FISH with microdissected probes from $17 \mathrm{p}+$ on normal metaphases. FITC signals painted distal fourth regions of chromosomes $1 \mathrm{c}$ (arrows) as well as normal $17 p$ (arrowheads). b: FISH with microdissected probes from the distal half region of normal chromosome $1 \mathrm{q}$ on patient $\mathrm{A}$ metaphases. FITC signals painted distal half regions of chromosomes Iq (arrows) and a distal region of $17 p+$ (arrowhead). $c$ : FISH with microdissected probes from $4 p+$ on control metaphases. FITC signals painted both distal regions of chromosomes 16 (arrows) and almost all segments of chromosome $4 \mathrm{p}$ (arrowheads). d: FISH with microdissected probes from the long arm of normal chromosome 16 on patient $B$ metaphases. FITC signals painted both normal 16q (arrows) and an interstitial region of $4 p+$ (arrowhead). 


\section{Discussion}

It has been shown that microdissected probes from Carnoy-fixed cells did not hybridize well in FISH analyses (Viersbach et al., 1994). On this poor hybridization it was suggested that depurination of DNA could occur during methanolacetic acid fixation (Holmquist, 1979). The depurinated sites are labile and may form nicks. And the size of DNA isolated from fixed preparations after aging for $24 \mathrm{hr}$ or more was diminished (Mezzanotte et al., 1988). Thus, to avoid depurination by acetic acid, Epstein-Barr virus-transformed lymphoblastoid cells or peripheral blood lymphocytes harvested in $100 \%$ methanol fixation were preferred to store at $-20^{\circ} \mathrm{C}$ until use, and a fixed cell suspension was mixed with acetic acid immediately prior to spread onto a clean glass-slide (Deng et al., 1992; Ohta et al., 1993; Ohashi et al., 1994).

However, recently, several reports using fixed cell suspensions by Carnoy's solution (methanol: acetic acid $3: 1$ ) have been published with minor differences. Carnoy's fixation was performed within $2 \mathrm{hr}$ before making slides and metaphase spreads were stored at $37^{\circ} \mathrm{C}$ for $2-3$ days (Guan et al, 1992). Recently, more impressive result was reported by Engelen et al. (1996). They used conventionally Carnoy-fixed cell suspensions stored at $-20^{\circ} \mathrm{C}$ for 3,5 , and 10 months. And chromosome preparations from Carnoy-fixed cells were stored in $98 \%$ ethanol at $-20^{\circ} \mathrm{C}$ until use. Furthermore, $\mathrm{Li}$ et al. (1995) reported on quality of DNA templates from Carnoy-fixed cells. They showed that there were no differences in quality of amplification products between PCR templates obtained from fresh tissues or from Carnoy-fixed cells for varying length of time ranging from a few weeks to 6 years, and that there was no apparent degradation of the DNA from Carnoy-fixed cells stored at $-20^{\circ} \mathrm{C}$. The results of present study confirmed these data, because we could successfully make the probes from stored Carnoy-fixed cell suspensions at $-20^{\circ} \mathrm{C}$ for $11 / 2$ and $41 / 2$ years.

Successful painting by probes made from Carnoy-fixed cells may be attributed to increased efficiency of PCR by Ex Taq polymerase used in this study. The Ex Taq polymerase formulation consists of a combination of a high level of an exonuclease-free $T a q$ polymerase with a low level of a thermostable DNA polymerase exhibiting a $3^{\prime}$-exonuclease activity (TaKaRa Shuzo Company). Polymerase combinations of this type could amplify long targets with high fidelity (Barnes, 1994; Cheng et al., 1994; Ermak et al., 1996).

FISH using microdissected probes is a useful technique for identification of the origin in cases with de novo chromosomal rearrangement. As indicated in this report, microdissected probes from old Carnoy's fixed cells were available for FISH analyses as same as from fresh cells. Thus, an application of this technique for marker chromosomes, in which its origins were not identified in the past trials, would support further genetic information to the patients with a marker chromosome. 


\section{REFERENCES}

Barnes WM (1994): PCR amplification of up to 35-kb DNA with high fidelity and high yield from $\lambda$ bacteriophage templates. Proc Natl Acad Sci USA 91: 2216-2220

Cheng S, Fockler C, Barnes WM, Higuchi R (1994): Effective amplification of long targets from cloned inserts and human genomic DNA. Proc Natl Acad Sci USA 91: 5695-5699

Deng H-X, Yoshiura K, Dirks RW, Harada N, Hirota T, Tsukamoto K, Jinno Y, Niikawa N (1992): Chromosome-band-specific painting: chromosome in situ suppression hybridization using PCR products from a microdissected chromosome band as a probe pool. Hum Genet 89: $13-17$

Eggermann T, Engels H, Moskalonek B, Nöthen MM, Müller-Navia J, Schleiermacher E, Schwanitz G, Stengel-Rutkowski S (1996): Tetrasomy 18p de novo: identification by FISH with conventional and microdissection probes and analysis of parental origin and formation by short sequence repeat typing. Hum Genet 97 : $568-572$

Engelen JJM, Loots WJG, Motoh PCC, Moog U, Hamers GJH, Geraedts JPM (1996): Marker chromosome identification by micro-FISH. Clin Genet 49: 242-248

Ermak G, Jennings T, Robinson L, Ross JS, Figge J (1996): Restricted patterns of CD44 variant exon expression in human papillary thyroid carcinoma. Cancer Res 56: 1037-1042

Guan X-Y, Horsman D, Zhang HE, Parsa NZ, Meltzer PS, Trent JM (1996): Localization by chromosome microdissection of a recurrent breakpoint region on chromosome 6 in human B-cell lymphoma. Blood 88: 1418-1422

Guan X-Y, Meltzer PS, Cao J, Trent JM (1992): Rapid generation of region-specific genomic clones by chromosome microdissection: isolation of DNA from a region frequently deleted in malignant melanoma. Genomics 14: 680-684

Hirota $T$, Tsukamoto $K$, Deng H-X, Yoshiura K, Ohta T, Tohma T, Kibe T, Harada N, Jinno $Y$, Niikawa $N$ (1992): Microdissection of human chromosomal regions 8q23.3-q24.11 and 2q33-qter: construction of DNA libraries and isolation of their clones. Genomics 13: 349-354

Holmquist $\mathrm{G}$ (1979): The mechanism of C-banding: depurination and $\beta$-elimination. Chromosoma 72 : 203-224

Li S, Tuck-Müller CM, Yan Q, Wertelecki W, Chen H (1995): A rapid method for PCR amplification of DNA directly from cells fixed in Carnoy's fixative. Am J Med Genet 55: 116119

Lüdecke H-J, Senger G, Claussen U, Horsthemke B (1989): Cloning of defined regions of the human genome by microdissection of banded chromosomes and enzymatic amplification. Nature 338: $348-350$

Meltzer PS, Guan X-Y, Burgess A, Trent JM (1992): Rapid generation of region specific probes by chromosome microdissection and their application. Nature Genet 1: $24-28$

Mezzanotte R, Vanni R, Flore O, Ferrucci L, Sumner AT (1988): Ageing of fixed cytological preparations produces degradation of chromosomal DNA. Cytogenet Cell Genet 48: 60-62

Müller-Navia J, Nebel A, Schleiermacher E (1995): Complete and precise characterization of marker chromosomes by application of microdissection in prenatal diagnosis. Hum Genet 96: $661-667$

Ohashi H, Wakui K, Ogawa K, Okano T, Niikawa N, Fukushima Y (1994): A stable acentric marker chromosome: possible existence of an intercalary ancient centromere at Distal 8p. Am J Hum Genet 55: 1202-1208

Ohta T, Tohma T, Soejima H, Fukushima Y, Nagai T, Yoshiura K, Jinno Y, Niikawa N (1993): The origin of cytologically unidentifiable chromosome abnormalities: six cases ascertained by targeted chromosome-band painting. Huin Genet 92: 1-5

Rubtsov N, Senger G, Kuzcera H, Neumann A, Kelbova C, Junker K, Beensen V, Claussen U (1996): Interstitial deletion of chromosome 6q: precise definition of the breakpoints by microdissection, DNA amplification, and reverse painting. Hum Genet 97: 705-709

Telenius H, Carter NP, Bebb CE, Nordenskjöld M, Ponder BAJ, Tunnacliffe A (1992): Degener- 
ate oligonucleotide-primed PCR: general amplification of target DNA by a single degenerate primer. Genomics 13: 718-725

Viersbach R, Schwanitz G, Nöthen MM (1994): Delineation of marker chromosomes by reverse chromosome painting using only a small number of DOP.PCR amplified microdissected chromosomes. Hum Genet 93: 663-667

Yokoyama Y, Sakuragawa N (1995): Improved simple generation of GTG-band specific painting probes. Cytogenet Cell Genet 71: 32-36

Vol. 42 , No. 4,1997 